\section{Effect of Surface Pretreatments on the Microtensile Bond Strength of Lithium-Disilicate Ceramic Repaired with Composite Resin}

Regina Cláudia Ramos Colares ${ }^{1,2}$, Jiovanne Rabelo Neri' ${ }^{2}$, André Mattos Brito de Souza ${ }^{2}$, Karina Matthes de Freitas Pontes ${ }^{2}$, Juliano Sartori Mendonça², Sérgio Lima Santiago ${ }^{2}$

\author{
'UNIFOR - University of \\ Fortaleza, Fortaleza, CE, Brazil \\ ${ }^{2}$ Department of Restorative Dentistry, \\ School of Pharmacy, Dentistry and \\ Nursing, UFC - Federal University \\ of Ceará, Fortaleza, CE, Brazil \\ Correspondence: Prof. Dr. Sérgio \\ Lima Santiago, Rua Monsenhor \\ Furtado, S/N, 60430-355 Fortaleza, \\ CE, Brasil. Tel/Fax: +55-85-3366- \\ 8232. e-mail: sergiosantiago@ufc.br
}

The aim of this study was to evaluate the influence of ceramic surface treatments and silane drying temperature on the microtensile bond strength $(\mu \mathrm{TBS})$ of a resin composite to a lithium disilicate ceramic. Twenty blocks $(7 \times 7 \times 5 \mathrm{~mm})$ of lithium disilicate-based hotpressed ceramic were fabricated and randomly divided into 4 groups: G1: acid etching with $9.5 \%$ hydrofluoric acid for $20 \mathrm{~s}$ and drying silane with room-temperature air; G2: acid etching with $9.5 \%$ hydrofluoric acid for $20 \mathrm{~s}$ and drying silane with $45 \pm 5{ }^{\circ} \mathrm{C}$ warm air; G3: airborne-particle abrasion with $50 \mu \mathrm{m}$ aluminum oxide particles and drying silane with $45 \pm 5{ }^{\circ} \mathrm{C}$ warm air; $\mathrm{G} 4$ : airborne-particle abrasion with $50 \mu \mathrm{m}$ aluminum oxide particles and drying silane with air at room-temperature. After treatments, an adhesive system (Single Bond 2) was applied, light-cured and direct restorations were built up with a resin composite (Filtek Z250). Each specimen was stored in distilled water at 37 ${ }^{\circ} \mathrm{C}$ for $24 \mathrm{~h}$ and cut into ceramic-composite beams with $1 \mathrm{~mm}^{2}$ of cross-sectional area for $\mu$ TBS testing. Statistical analysis was performed with one-way ANOVA and StudentNewman-Keuls test $(\alpha=0.05)$. $\mu$ TBS means (S.D.) in MPa were: G1: 32.14 (7.98), G2: 35.00 (7.77) and G3: 18.36 (6.17). All specimens of G4 failed during the cutting. G1 and G2 presented significantly higher $\mu$ TBS than $\mathrm{G} 3(p<0.05)$. There was no statistically significant difference between $\mathrm{G} 1$ and $\mathrm{G} 2$ ( $p>0.05$ ). As far as the bond strength is concerned, surface pretreatment of lithium-disilicate ceramic with hydrofluoric acid and silane application can be used as an alternative to repair ceramic restorations with composite resin, while surface pretreatment with sandblasting should be avoided.
Key Words: surface treatment, lithium disilicate ceramic, bond strength.

\section{Introduction}

The increasing demand for esthetics in restorative dentistry has led to the development of all-ceramic restorations using different resin-based adhesive systems, since they provide excellent esthetic metal-free characteristics $(1,2)$. However, the physical and bonding properties of ceramics are still problematic (2).

The establishment of a durable and reliable bond between dental ceramic and resin composite is important in dental practice because of its extensive use. This bond is usually created via two mechanisms: micro-mechanical attachment by hydrofluoric acid (HF) etching and/or sandblasting, and chemical bonding by a silane coupling agent (3). Effective etching of the ceramic surface is considered an essential step for the clinical success of indirect ceramic-bonded restorations and direct ceramic repair procedures (4). Acid etching increases the surface area and the wettability of ceramics, changing their surface energy and the bonding potential of ceramic to resin $(5,6)$.

The bonding properties between resin-based adhesives and ceramics are mainly associated with the presence of silica on the surface that provides chemical compatibility mediated by silane-coupling agents (7). The incorporated silica of acid-sensitive ceramics such as lithium disilicate ceramics is well-exposed by $\mathrm{HF}$ acid gel to give increased surface roughness, which is available for mechanical interlocking $(4,6,7)$.

The use of silane is recommended for glasses and porcelains in order to form a siloxane network with the silica in the ceramic surface, to improve the bond strength between the ceramic and luting material $(8,9)$. Silane-coupling agents, because of their chemical compatibility and the micro-roughness on the acid-etched surface, allow for sufficient bonding properties by mediating between the ceramics and resin-based adhesives (10).

To accelerate the mechanism of chemical interaction of silane, the reaction is usually catalyzed by acid or heat (11). The heat treatment can also evaporate solvent and volatile reaction products are formed during condensation of silanol groups (12). It is also possible that heating of silane-coated ceramic 
might facilitate vaporization and elimination of excess silane from the surface (5).

The lithium disilicate based E-max (IPSe.max CAD; Ivoclar Vivadent, Schaan, Liechtenstein) is a new ceramic material and there is not enough information about the effects of pretreatment methods on the bond strength of ceramic repairs with composite. The purpose of this in vitro study was to evaluate the influence of ceramic surface treatments and the silane drying temperature on the microtensile bond strength ( $\mu$ TBS) resin composite to a lithium disilicate ceramic. The hypothesis tested was that the use of warm-air after silane application could increase the tensile bond strength of composite to disilicate based ceramic.

\section{Material and Methods}

Twenty hot-pressed ceramic blocks $(7 \times 7 \times 5 \mathrm{~mm})$ were fabricated from partially crystallized lithium disilicatebased glass blocks (IPSe.max CAD; Ivoclar Vivadent). The ceramic blocks were mechanically polished using silicone rubbers impregnated with diamond (Exa-Cerapol; Edenta $A G, A U / S G$, Switzerland) at low speed. After polishing, all ceramic blocks were ultrasonically cleaned in distilled water for $10 \mathrm{~min}$ and dried with oil-/water-free air for $60 \mathrm{~s}$.

The specimens were randomly allocated in 4 groups $(n=5)$ by the Excel software (Excel 2003; Microsoft Corporation, One Microsoft Way, Redmond, WA, USA), according to the following surface treatments and silanization protocols: $\mathrm{G} 1$ : 9.5\% hydrofluoric acid was applied for $20 \mathrm{~s}$ and silanated surface was dried at room temperature $\left(23^{\circ} \mathrm{C}\right) ; \mathrm{G} 2:$ : 9.5\% hydrofluoric acid was applied for $20 \mathrm{~s}$ and silanated surface was dried with warm air at $45 \pm 5^{\circ} \mathrm{C} ; \mathrm{G} 3$ : sandblasting with $50 \mu \mathrm{m}$ aluminum oxide particles (Bio Art, São Carlos, SP, Brazil) for $5 \mathrm{~s}$, applied perpendicularly to the surface at a pressure of $30 \mathrm{psi}$ from a distance of approximately $10 \mathrm{~mm}$ and silanated surface was dried with warm air at $45 \pm 5$ ${ }^{\circ} \mathrm{C}$; G4: sandblasting with $50 \mu \mathrm{m}$ aluminum oxide particles (Model Standard; Bio Art) for $5 \mathrm{~s}$, applied perpendicularly to the surface at a pressure of $30 \mathrm{psi}$ and from a distance of approximately $10 \mathrm{~mm}$ and silanated surface were dried with room-temperature air.

After the surface treatments, the blocks were rinsed with air-water spray for $30 \mathrm{~s}$, dried with oil-water-free air blast for $30 \mathrm{~s}$, and silane (Rely-X Ceramic Primer; 3M-ESPE Dental Products, St. Paul, MN, USA) was applied with a brush, left undisturbed for $1 \mathrm{~min}$, and the surface was subjected to one of the following drying procedures: $\mathrm{G} 1$ and $\mathrm{G} 4$ ceramic blocks were dried at room-temperature air $\left(23^{\circ} \mathrm{C}\right)$, allowing the silane to penetrate into the surface irregularities for 1 $\min$, then gently blowing off the excess with an air blast at approximately $20 \mathrm{~cm}$ from the surface. $\mathrm{G} 2$ and $\mathrm{G} 3$ ceramic blocks were dried with a stream of warm air $\left(45 \pm 5{ }^{\circ} \mathrm{C}\right)$ generated from a blow dryer (model RV456ABG; Revlon, El Paso, TX, USA) for $15 \mathrm{~s}$ to approximately $15 \mathrm{~cm}$ from the surface. The air temperature was measured by digital portable thermometer (model MT 600; Minipa, São Paulo, $\mathrm{SP}$, Brazil) with a resolution of $0.1{ }^{\circ} \mathrm{C}$, a basic precision of $0.1 \pm 0.7 \%$, and with a temperature range from 0.1 to $200{ }^{\circ} \mathrm{C}$. An etch-and-rinse adhesive system (Adper Single Bond 2; 3M ESPE) was applied according to manufacturer's instructions: apply two coats of adhesive, air-drying for 10 $\mathrm{s}$ at $20 \mathrm{~cm}$ and light-curing for $10 \mathrm{~s}$. After light curing of the adhesive system, 5 increments of $1 \mathrm{~mm}$ thickness of composite resin (Filtek Z250; 3M ESPE) were build-up. Each increment was light-cured with a halogen light-curing unit (VIP Junior; Bisco Inc., Schaumburg, IL, USA) for 40 s, with power density of $500 \mathrm{~mW} / \mathrm{cm}^{2}$. The bonded ceramic blocks were stored in distilled water at $37^{\circ} \mathrm{C}$ for $24 \mathrm{~h}$.

The ceramic-resin blocks were longitudinally sectioned in both the " $x$ " and " $y$ " directions across the bonded interface using a diamond saw in a Labcut 1010 machine (Extec Corp., Enfield, CT, USA) under water cooling to obtain bonded sticks with a cross-sectional area approximately 1.0 $\mathrm{mm}^{2}$. The cross-sectional area of each stick was measured with the digital caliper (Absolute Digimatic, Mitutoyo, Tokyo, Japan) to the nearest $0.01 \mathrm{~mm}$ and recorded for subsequent calculation of the $\mu$ TBS. In all blocks, the first slice was discarded because results could be influenced by excess or lack of adhesive at the interface.

For $\mu$ TBS testing, each specimen was attached with cyanoacrylate glue (Zapit; Dental Venture of America Inc., Corona, CA, USA) to a modified Bencor Mult-T testing apparatus (Danville Engineering Co., Danville, CA, USA) and subjected to a tensile force at $1.0 \mathrm{~mm} / \mathrm{min}$ crosshead speed in a universal testing machine (Instron 4484; Instron Inc., Canton, MA, USA). The load at fracture was used to calculate bond strength and expressed in MPa.

After the $\mu$ TBS testing, the fractured surfaces of both ceramic side and resin side were investigated using a stereoscope (StereoZoom ${ }^{\circledR}$ Leica S8 APO; Leica Microsystems, Wetzlar, Germany) at $80 \times$ magnification. The failure modes were classified as adhesive failure (1) when occurred at the ceramic/resin interface; cohesive failure (1) when fractured exclusively within ceramic or resin composite; or mixed failure (3) when two modes of failure happened simultaneously.

Bond strength values were analyzed statistically with one-way ANOVA and Student-Newman-Keuls test at 5\% significance level. Statistical procedures were performed using the STATA SE 9.1 for Windows statistical program software (STATA; College Station, TX, USA). Stick was used as statistical unit and the number of prematurely debonded specimens was recorded but was not included in the analysis. 


\section{Results}

The results were influenced by surface treatment among the groups. $\mathrm{G} 1$ and $\mathrm{G} 2$ showed no significant differences between them ( $p>0.05$ ) and values of bond strength were significantly higher than those recorded in $\mathrm{G} 3(\mathrm{p}<0.01)$ (Table 1). All G4 specimens failed during the procedure of cutting and were eliminated.

The prevalent fracture pattern in all groups was the mixed failure (Table 2).

\section{Discussion}

The clinical success of either a repaired ceramic restoration or a resin cemented ceramic restoration depends on the quality and durability of the bond between the ceramic and the resin. To obtain reliable bond strength between resin composite and ceramic materials, mechanical retention performed with surface roughening and chemical retention with silane agent is essential (13).

The application of hydrofluoric acid in ceramic surface promotes the reaction with the glass matrix that contains silica and forms hexafluorosilicates. This glass matrix is selectively removed and the crystalline structure is exposed. As a result, the surface of the ceramic becomes rough, which is expected for micromechanical retentions (6). This roughly etched surface also helps to provide more surface energy prior to combining with the silane solution (14). Some studies have demonstrated that roughening the ceramic surface by etching has been considered the most effective procedure of retaining the bond integrity $(12,14)$ and for the clinical success of indirect ceramic bonded restorations and direct-repaired ceramic prostheses (15-21). This data corroborate the results of the present study (Table 1).

Heating of silane on the surface of ceramics can promote better adhesion between this material and resin composite $(3,5,11,22)$. The heating of silane on the surface of ceramics can eliminate water, alcohol and byproducts of the reaction and help to complete the condensation reaction of silanesilica promoting the formation of siloxane (22). Evaporation of alcohol or acetic acid can increase the density of local connections available for the solution of silane react with the ceramic (22). However, in the present study no statistical differences were found between samples treated with

Table 1. Microtensile bond strength according to the surface treatments

\begin{tabular}{lc}
\hline Group & Microtensile bond strength \\
\hline G1 & $32.14 \pm 7.98^{\mathrm{A}}(\mathrm{n}=33)$ \\
G2 & $35.00 \pm 7.77^{\mathrm{A}}(\mathrm{n}=32)$ \\
G3 & $18.36 \pm 6.17^{\mathrm{B}}(\mathrm{n}=20)$ \\
\hline
\end{tabular}

Same letters indicate no statistically significant difference $(p>0.05)$. Results are given in $\mathrm{MPa} \pm$ SD (n). hydrofluoric acid and single-bottle silane dried with air at room temperature or heated at $45 \pm 5{ }^{\circ} \mathrm{C}$, rejecting the hypothesis. Barghi et al. (23) demonstrated that different kinds of silanes yield different bond strength values. These authors also found differences in bond strengths following thermal treatment of silanated porcelain using two-bottle silanes, whereas prehydrolized single-bottle silanes were not affected by this procedure. Different silanes may present in their composition different solvents which will influence their reactivity and stability in various ways (20).

On the other hand, sandblasting as a surface pretreatment reduced the bond strength (Table 1). According to Chen et al. (20), sandblasting should be avoided due to the possibility of volume loss and changes in the morphology of ceramics. However, in the present study, the specimens could be tested when heated silane was used, unlike in G4. Probably, in this case, the heating promoted the condensation reaction within silane that would reduce the thickness of the silane and prevent it from incorporation with the adhesive resin applied later (24). Without the heat treatment, the silane on the ceramic surface could blend with the adhesive resin, forming a continuous layer of adhesive between the ceramic and the composite. A study has shown that the high concentration of silane in the solution (greater than $5 \%$ ) has a negative effect on the bond strength values (2).

The prevalent fracture pattern of G1, G2 and G3 was the mixed failure (Table 2). These findings suggest that the bond between single-bottle silane and the porcelain are a proportional mixing of chemical and mechanical bonds. These data were in accordance with those of other studies $(12,23,25)$.

The present study was limited to the investigation of the effect of post silanization with warm-air drying to seek an alternative treatment modality of clinically applicable heat treatment of silane. Further laboratory tests need to be conducted, using a similar methodology but with thermocycling and another silane composition, to investigate how this could influence the bond strength of lithium-disilicate ceramics to resin composite.

In conclusion, the findings of this study showed that the surface pretreatment of lithium-disilicate ceramic

Table 2. Distribution of fracture pattern according to groups. Relative percentage is in parentheses

\begin{tabular}{lcccc}
\hline Group & $\begin{array}{c}\text { Premature } \\
\text { failure }\end{array}$ & $\begin{array}{c}\text { Adhesive } \\
\text { failure }\end{array}$ & $\begin{array}{c}\text { Cohesive } \\
\text { failure }\end{array}$ & Mixed failure \\
\hline G1 & $0(0 \%)$ & $2(6.5 \%)$ & $1(3.2 \%)$ & $30(90.3 \%)$ \\
G2 & $0(0 \%)$ & $1(3.2 \%)$ & $0(0)$ & $31(96.8 \%)$ \\
G3 & $0(0 \%)$ & $0(0 \%)$ & $0(0 \%)$ & $20(100 \%)$ \\
\hline
\end{tabular}


with hydrofluoric acid and the application of silane can be used as an alternative to repair ceramic restorations with composite resin. On the other hand, surface pretreatment with sandblasting should be avoided.

\section{Resumo}

0 objetivo deste estudo foi avaliar a influência dos tratamentos de superfícies e a temperatura de secagem do silano na resistência de união de resina composta à cerâmica de disilicato de lítio. Vinte blocos (7x7 $\times 5 \mathrm{~mm})$ de cerâmica à base de disilicato de lítio foram fabricados e aleatoriamente divididos em quatro grupos: $\mathrm{G} 1$ : condicionamento com ácido fluoridrico a 9,5\% por 20 s e secagem do silano com ar à temperatura ambiente; G2: condicionamento com ácido fluorídrico a $9,5 \%$ por 20 s e secagem do silano com ar aquecido a $45 \pm 5{ }^{\circ} \mathrm{C} ; \mathrm{G} 3$ : jateamento com partículas de óxido de alumínio de $50 \mu \mathrm{m}$ e secagem do silano com ar aquecido a 45 $\pm 5{ }^{\circ} \mathrm{C} ; \mathrm{G} 4$ : jateamento com partículas de óxido de alumínio de $50 \mu \mathrm{m}$ e secagem do silano com ar à temperatura ambiente. Após os tratamentos, o adesivo Adper Single Bond 2 foi aplicado, fotoativado e foi construido um platô de resina composta (Filtek Z250). Cada espécime foi armazenado em água destilada a $37{ }^{\circ} \mathrm{C}$ por $24 \mathrm{~h}$ e cortados em forma de palito de área adesiva de $1 \mathrm{~mm}^{2}$ para a realização do teste de microtração. Os dados foram submetidos à ANOVA e ao teste de Student-Newman-Keuls $(\alpha=0,05)$. As médias (D.P.) dos valores de resistência de união em $\mathrm{MPa}$ foram: G1: $32,14(7,98), \mathrm{G} 2: 35,00(7,77)$ e $\mathrm{G} 3: 18,36(6,17)$. G1 e G2 apresentaram maiores valores de resistência de união que $G 3(p<0,05)$. Não houve diferença estatística entre as médias dos valores dos grupos G1 e G2 ( $>>0,05)$. Levando-se em consideração a resistência de união, o pré-tratamento de cerâmica de disilicato de lítio com ácido fluorídrico e ¿ aplicação de silano pode ser uma alternativa para o reparo de restaurações $\star$ de cerâmicas com resinas compostas, enquanto que o pré-tratamento de superfície com o jateamento deve ser evitado.

\section{References}

1. Yavuz T, Dilber E, Kara HB, Tuncdemir AR, Ozturk AN. Effects of different surface treatments on shear bond strength in two different ceramic systems. Lasers Med Sci 2012;13 [Epub ahead of print. DOI: 10.1007/ s10103-012-1201-5].

2. Yoshida $K$, Tsuo Y, Atsuta M. Bonding of dual-cured resin cement to zirconia ceramic using phosphate acid ester monomer and zirconate coupler. J Biomed Mater Res B: Appl Biomater 2006;77:28-33.

3. Hooshmand T, VanNoort R, Keshvad A. Bond durability of the resinbonded and silane treated ceramic surface. Dent Mater 2002;18:179188.

4. Della Bona A, Anusavice KJ. Microstructure, composition, and etching topography of dental ceramics. Int J Prosthodont 2002;15:159-167.

5. Della Bona A, Shen C, Anusavice KJ. Work of adhesion of resin on treated Lithia disilicate-based ceramic. Dent Mater 2004;20:338-344.

6. Zogheib LV, Della Bona A, Kimpara ET, Mccabe JF. Effect of hydrofluoric acid etching duration on the roughness and flexural strength of a lithium disilicate-based glass ceramic. Braz Dent J 2011;22:45-50.

7. Ozcan M, Vallittu PK. Effect of surface conditioning methods on the bond strength of luting cement to ceramics. Dent Mater 2003;19:725731.

8. Corazza PH, Cavalcanti SC, Queiroz JR, Bottino MA, Valandro LF. Effect of post-silanization heat treatments of silanized feldspathic ceramic on adhesion to resin cement. J Adhes Dent 2013;15. doi: 10.3290/j.jad. a29592. [Epub ahead of print].

9. Derand T, Molin M, Kvam K. Bond strength of composite luting cement to zirconia ceramic surface. Dental Mater 2005;21:1158-1162.

10. Tanaka R, Fujishima A, Shibata Y, Manabe A, Miyazaki T. Cooperation of phosphate monomer and silica modification on zirconia. J Dent Res 2008;87:666-670.

11. Fabianelli A, Pollington S, Papacchini F, Goracci C, Cantoro A, Ferrari $M$, et al.. The effect of different surface treatments on bond strength between leucite reinforced feldspathic ceramic and composite resin. J Dent 2010;38:39-43.

12. Roulet JF, Söderholm KJ, Longmate J. Effects of treatment and storage conditions on ceramic/composite bond strength. J Dent Res 1995;74:381-387.

13. Kim Bo-k, Bae HE-K, Shim J-S. The influence of ceramic surface treatments on the tensile bond strength of composite resin to allceramic coping materials. J Prosthet Dent 2005;94:357-362.

14. Jardel V, Degrange M, Picard B, Derrien G. Correlation of topography to bond strength of etched ceramic. Int J Prosthodont 1999;12:59-64.

15. Kara HB, Ozturk AN, Aykent F, Koc O, Ozturk B. The effect of different surface treatments on roughness and bond strength in low fusing ceramics. Lasers Med Sci 2011;26:599-604.

16. Yen TY, Blackman RB, Baez RJ. Effect of acid etching on the flexural strength of a feldspathic porcelain and a castable glass ceramic. J Prosthet Dent 1993;70:224-233.

17. Della Bona A, Anusavice KJ, Mecholsky Jr JJ. Failure analysis of resin composite bonded to ceramic. Dent Mater 2003;19:693-699.

18. al Edris A, al Jabr A, Coley RL, Barghi N. SEM evaluation of etch patterns by three etchants on three porcelains. J Prosthet Dent 1990;64:734739.

19. Kupiec KA, Wuertz KW, Barkmeir WW, Wilwerding TM. Evaluation of porcelain surface treatments and agents for composite-to-porcelain repair. J Prosthet Dent 1996;76:119-124.

20. Chen TM, Brauer GM. Solvent effects on bonding organosilane to silica surfaces. J Dent Res 1982;61:1439-1443.

21. Della Bona $A$, van Noort R. Ceramic surface preparations for resin bonding. Am J Dent 1998;11:276-280.

22. Shen $\mathrm{C}, \mathrm{Oh}$ WS, Williams JR. Effect of post-silanization drying on the bond strength of composite to ceramic. J Proshet Dent 2004;91:453458.

23. Barghi N, Berry T, Chung K. Effects of timing and heat treatment of silanated porcelain on the bond strength. J Oral Reab 2000;27:407-412.

24. Debnath S, Wunder SL, McCool JI, Baran GR. Silane treatment effects on glass/resin interfacial shear strengths. Dent Mater 2003;19:441-448.

25. Appeldoorn RE, Wilwerding TM, Barkmeier WW. Bond strength of composite resin to porcelain with newer generation porcelain repair systems. J Prost Dent 1993;70:6-11.

Received October 3, 2012 Accepted June 14, 2013 